\title{
A Comparison of Tourist Evaluation of Beaches in Malta, Romania and Turkey
}

\author{
F BRIAN BLAKEMORE \\ University of Glamorgan, UK \\ Allan T. Williams \\ Florida International University, USA \\ Claudia Coman \\ National Institute for Marine Research and Development, Ramania \\ Anton Micallef \\ University of Malta \\ OzLEM UNAL \\ Dokuz Eylul University, Turkey
}

\begin{abstract}
The characteristics, perceptions, attitudes and behaviour of beach users at three locations: St George's Bay, Malta, Mamaia, Romania and Olu Deniz, Turkey, were determined from questiannaire surveys. Respondents comprised locals, domestic ond foreign tourists. Results far these parameters had substantial agreement both across the three beaches and with previaus studies. The amounts beach users were willing to pay (WTP), via the contingent valuation method and their consumer surpluses (CS), via the travel cost method were determined. The average amount beach users were willing to pay per visit, was $£ 0.64$ on St George's bay, $£ 0.32$ on Mamaia and $£ 0.94$ on Olu Deniz. The willingness to pay varied with social closs, earnings, amount of beach use and between local, domestic and foreign user groups. The consumer surplus also varied for these groups as British tourists had a CS of $£ 0.62$ per visit, with domestic Turkish ond Ramanian users having values of $£ 0.46$ and $£ 0.69$, respectively. Diminishing marginal utility, as measured by WTP, with beach use was found in all three surveys. Charging far actual use would be acceptable for the majarity of beach users. Coastal zone managers could realise significant revenues from beach users if they charge adults on a per visit basis (the favaured mode of payment) and spend the revenue on the maintenance and improvements identified by the users. Only one of the beaches (Olu Deniz, Turkey) currently has restricted access, which would facilitate such a payment methad.
\end{abstract}

Keywords: Beach, perception, contingent valuation, travel cost, consumer surplus, willingness to pay, Malta, Romania, Turkey

\section{Introduction}

Tourism on a world scale is massive, and there appears to be a crucial relatianship between tourism and the beach (Raybould and Mules, 1999). For the USA, Haustan (1996) has shawn that beaches are the leading taurist destinatians. Eighty-five percent af all taunst revenues are earned by coastal states largely due to the attroction of beaches. Miami attracts mare than twice the number af people (21 millian) wha visit the Grand Canyan, Yasemite and Yellowstone National Parks annually. In the Mediterranean an explosion of internatianal visitars has occurred with mare than 198 millian visitars 
compared to a world tourism trode af 620 million and beaches are the main ottractions (MMT, 1999). For example, the target set by the Turkish government for 2001 is 12 million tourists. This record level will require an investment of $\$ 3.41$ per tourist and is part of a plan ta move away from low income tourists ta those having higher earnings and therefore higher spending patential (Anon, 2001).

This huge industry hos spawned many researchers who have written myriod papers on the subject. However, the number of research papers written from the viewpoint of beach users is relatively smoll. This paper analyzes responses from beach users in three countries (two in the Mediterraneon and one in the Black Sea). The three beaches selected are all located in prime tourist areas, sited either very close to urban areas or ore actually within an urban areo (St George's, Malto). Respondents' ratings af the appearonce of these three beaches were found to be excellent (Olu Deniz, Turkey), good (Mamaia, Romania) and fair (St George's, Molta).

The relationships between attitudes to ond perceptions of the beach, beach use, sacio-economic demagraphics and tourist types, were compared with: users stated (hypotheticol) economic valuotions for using the beach (Willingness To Pay) together with an estimate of their consumer surplus estimated from their travel cost demand schedule. To test the volidity of using a hypothetical value, users were asked their expenditure on other leisure activities. The concept of diminishing marginal utility, which is expected for consumption of any good, was used to further test the validity of this hypothetical data. The validity of both willingness to pay using contingent valuation (hypothetical scenario) and cansumer surplus using the travel cost method have been subject to debate for over twenty years. For a brief review of the literature see Blakemore et al., (2000).

\section{Methodology}

A questiannaire was designed and given to beach users at three selected beaches in Malta $(n=60)$ Romania, $(n=50)$ and Turkey, $(n=$ 91). The size af the survey was limited by resaurce availability. The data for Turkey includes o pilat sample $(n=30)$ carried out previously. The questionnaire covered items such as their views of beach attractiveness and their willingness to pay (WTP) to use/maintain the beach. At each beach on attempt was made to interview every fifth person/group encountered either entering the beach area (Malta) or sitting on the beach. A very low non-response rate (1\%) was experienced in all three surveys. This approach excludes beach users actively swimming etc. from the sample. However, many respondents cited swimming and other active leisure pursuits as o major port of their beach activities, which coupled with comparisans with the results of other larger surveys (see results \& discussion) suggest that the sample may be taken to be a good representotion of the beach population. Standard techniques of analyses were utilised in order to evaluate ecanamic concepts such as WTP and CS. WTP was ascertained using an open-ended format i.e., the respondents valuation was not prampted in any way by the questionnaire nor by the interviewer.

Three of the four surveys (including the pilot in Turkey) were carried out in August, the high point of the summer season, whilst the fourth was corried out in May a less intense period for beach use. All surveys were carried out on a weekday, throughout the day from mid-morning until early evening.

Two of the beaches selected were among the most popular destinations in those countries for British tourists, which ollowed for a comparison of this notionality on different beaches and in different countries. The third beach was in a country undergoing a transition from "classi$\mathrm{cal}^{\prime \prime}$ communist management to o new entrepreneurial regime.

The three beaches are physically very different and represent, according to their beach users, different levels of quality of experience, ranging across the spectrum poor, good and excellent.

Thus, selecting these three beaches and the two seasons allowed the study to analyse many factors that might affect the economic valuatian placed upon the beach experience.

\section{The Beaches}

a) Mamaia, Romania

This is the biggest coastal resort in Ramania with a $8 \mathrm{~km}$ lang beach locoted on a narrow sand bor some $250 \mathrm{~m}$ in width between Siutghial 
Lake in the west and the sea to the east. It is linked to the City of Constonta by o wide highway. The beach is formed af terrigenous sediments brought by the river Danube plus organogenous sediments. The sand is a pale yellow in colour and is fine groined. Coastal erosion is a large problem due to extension dykes especiolly at Midia Harbour, which interrupts the flow of longshore sediments. Six coastal defence structures in the form of offshore breakwaters (at a $5 \mathrm{~m}$ depth) run parallel to the shore. In addition some $2 \mathrm{~km}$ of beach has hod beach nourishment. The beoch slopes gently to a depth of $4 \mathrm{~m}$. and has many access points. Local bar/cofé owners are taking advantoge of the "post-communist" era by plocing their tables, chairs etc. on the beach in front of their premises. This "beach appropriation" could be utilised to collect any charge imposed for beach use.

\section{b) Olu Deniz, Turkey}

Olu Deniz, locoted within the Fethiye special protection area, consists of a long spit (2-3 km) $100-200 \mathrm{~m}$ wide with a beach composed of cobble sized materiols. There is essentially only one entrance obout holf woy down the spit and it is located some 20 minutes drive from the large tourist resort town of Marmaris on the Mediterranean coast and is probably the most popular Turkish beach. Morgan and Williams (1998) and Morgan et al., (1995) carried out a pilot study of beach user opinions and calculated their own beach rating for five Turkish beaches $(n=245)$. Olu Deniz, gave the highest rating $(87 \%)$ bosed upon weighted values for 47 different aesthetic ospects. Further aesthetics study surveys by Williams et al., (2000) have shown that out of 28 tourist beaches located between Izmir and Antalya, this beach rated number 3 and the adjacent lagoon number 4 . Over 210,000 visitors arrive by air at the nearby Dalaman Airport for August (BTS, 1999) and some 15,000 orrive by sea. The single entrance point cauld be used to collect fees.

\section{c) St George's, Molta}

St. George's Bay is located about $3 \mathrm{~km}$ from Volletto and consists af a roughly rectangular bay $600 \mathrm{~m}$ long by $200 \mathrm{~m}$ wide with two small pockets of sand accumulations located at the Northwest and Sautheast corners. Elsewhere the water line is represented by bare rock or
Table 1. Demographics for the three beaches: St George's Bay, Malta, Mamaia Beach, Romania and Olu Deniz b=Beach, Turkey

\begin{tabular}{lccc}
\hline & Malta & Romania & Turkey \\
\hline Sample size & 60 & 50 & 91 \\
Locals & $17 \%$ & $23 \%$ & $5 \%$ \\
Domestic tourists & $3.3 \%$ & $77 \%$ & $16 \%$ \\
British & $40 \%$ & $\#$ & $74 \%$ \\
Dutch & $18 \%$ & $\#$ & - \\
Others & $21.7 \%$ & $\#$ & $5 \%$ \\
Age profile, & 40.7 & 35.1 & 34.6 \\
mean & years & years & yeors \\
Age profile, & $21-75$ & $18-60$ & $18-65$ \\
range & years & years & years \\
Number af & $1-30$ & $1-4$ & $1-5$ \\
adults in group & & & \\
Children in group & $10 \%$ & $50 \%$ & $37 \%$ \\
$\begin{array}{l}\text { Number children } \\
\text { in group }\end{array}$ & $0-2$ & $0-2$ & $0-4$ \\
Prafessional & $37 \%$ & $44 \%$ & $31 \%$ \\
Skilled- manual & $34 \%$ & $38 \%$ & $59 \%$ \\
Retired, student & $29 \%$ & $18 \%$ & $10 \%$ \\
unemployed. & & & \\
Mean earnings & $£ 18,400$ & $£ 1,023$ & $£ 14,300$ \\
\hline & p.a. & p.a. & p.a. \\
\hline
\end{tabular}

\# The ariginal sample had 3 respondents fram Western Europe, which were discarded.

else mast commonly by a hard concrete quay. These two 'pocket beaches' correspond to discharge points of two watercourses within the watershed of the bay. A road backed by a low wall seporates the beoch from the hinterland. A beach naurishment progromme is planned which would extend the beach some $40 \mathrm{~m}$ seawards. Collection of fees for beach use would not be a prablem since the proposed beach nourishment envisages construction of a wide promenade to separate the existing road from the beach, thereby limiting access to two points which would be appropriate collection points.

\section{Results and Discussion}

a) Demographics

The age profiles for beoch users are similor for all three beaches (Table 1). However, users an St George's, Malta, had an older profile. The time of the Malta survey (May, 2000) does not seem to have significantly offected the demographics as tourism data far Malta reflects that older tourists ore not solely limited to 'shoulder months'. Far example, data for the year 
ist orrivals were more than 65 years old, followed in $2^{\text {rd }}$ place by $45-49$ year olds and jointly in $3^{\text {rit }}$ place were 50-54 and 25-29 year olds (NTOM, 1997). Respondents mainly represent fomily groupings with one to five odults and zero to four children. Again, the picture at St George's is slightly different with some respondents having come as part of a large party of adults.

Classification by occupation (Table 1) gave similar results for St George's, Malta and Mamaia, Romania, with a higher proportion af skilled, semi-skilled and manual workers and a lower proportion of retired or student respondents than the sample at Olu Deniz, Turkey.

Average earnings of the British tourists in the Maltese survey was $£ 21,000$ well above the British average of $£ 18,200$ (Hinde, 1998), whereas the British tourist average value in Turkey of $£ 16,500$ was well below the British averoge. This is partly due to higher incomes enjoyed by the retired respondents in Malta compared to the

Table 2. Beach use

\section{a) Frequency of visiting the beach:}

\begin{tabular}{lccc}
\hline & Malto & Romania & Turkey \\
\hline Everyday & $16 \%$ & $64 \%$ & $32 \%$ \\
most days & $58 \%$ & $16 \%$ & $53 \%$ \\
one day/ week & $26 \%$ & $20 \%$ & $15 \%$ \\
or less & $(17 \%$ locals) & (all locals) & \\
$\begin{array}{l}\text { Duration in } \\
\text { days, excluding (one of } 28)\end{array}$ & $5-14$ & $6-14$ \\
locols & &
\end{tabular}

b) Duration of eoch beoch visit:

\begin{tabular}{lccc}
\hline & Malto & Romonio & Turkey \\
\hline less than I hr & $14 \%$ & $0 \%$ & $1 \%$ \\
$1-4$ hours & $64 \%$ & $54 \%$ & $35 \%$ \\
$4-8$ hrs & $15 \%$ & $40 \%$ & $56 \%$ \\
more than 8 hours & $7 \%$ & $6 \%$ & $8 \%$
\end{tabular}

averages for these samples (Table 1) are also of fected by the standard of living enjayed in that country and by the other nationalities within the samples. For the Romanian survey the average earnings seem very high compared with a typical salary for e.g. a medical doctor in Romania, circa $£ 61$ per month but there is on extensive block morket thot makes afficial figures a gross underestimate of real earnings.

b) Beach use, perceptions ond attitudes

With the exception of local residents, most visitors were on vacation for either one or two weeks. There was limited evidence of longer stay visits by retired people in the off peak season survey in Malta. Frequency of beach visits was also similar for thase not local to the resort (Table 2). The proportion using the beach most doys or every day was slightly lower for St George's, Malta (74\%) than for the other two locations ( $80 \%$ Romania and $85 \%$ Turkey).

In all three surveys the vast mojority of users spend between 1 and 8 haurs on the beach per visit. This confirms findings on other beaches in the world e.g. $85 \%$ in metropolitan Adelaide (Anon., 1988). Reasons for visiting the beach are given in Table 2, which indicates that the users on all three beaches had similar purposes in mind; "views and fresh air" was the primary reason fallowed by swimming and walking. Enjoying nature and wildlife was a small part of the Romanian experience but a significant part of the Turkish one.

The high value of enjoyment on Mamaia Beach, Romania, expressed as a proportion of the total holidoy enjoyment $(84 \%)$, is in contrast to that found for foreign tourists on the Turkish beach $(60 \%)$ but compores favourably with Australian research studies e.g. Anon. (1988) that gave a value of $80 \%$. This may reflect the fact

c) Recreotional octivities:

\begin{tabular}{lcccccc}
\hline & $\begin{array}{c}\text { View and } \\
\text { fresh air }\end{array}$ & Swimming & Wolking & Children's play & Water sports & $\begin{array}{c}\text { Nature } \\
\text { \& wildlife }\end{array}$ \\
\hline Molto & $67 \%$ & $28 \%$ & $39 \%$ & $11 \%$ & $10 \%$ & $16 \%$ \\
Romonia & $76 \%$ & $56 \%$ & $34 \%$ & $22 \%$ & $22 \%$ & $2 \%$ \\
Turkey & $77 \%$ & $\star$ & $\star$ & $\star$ & $*$ & $24 \%$ \\
\hline
\end{tabular}

NB. The survey in Olu Deniz, Turkey did not break recreatian down into these cotegories, however the response for "recreation" was 100\%. 
Table 3. Beach aesthetics:

\begin{tabular}{|c|c|c|c|c|c|c|c|c|c|c|}
\hline \multicolumn{11}{|c|}{ a) Appearance of beach } \\
\hline & & Enjoyment* & \multicolumn{2}{|c|}{ excellent } & good & \multicolumn{2}{|r|}{ foir } & \multicolumn{2}{|l|}{ poor } & bad \\
\hline Malta & & $47 \%$ & \multicolumn{2}{|c|}{$7 \%$} & $17 \%$ & \multicolumn{2}{|r|}{$44 \%$} & \multicolumn{2}{|l|}{$25 \%$} & $7 \%$ \\
\hline Romania & & $84 \%$ & \multicolumn{2}{|c|}{$8 \%$} & $54 \%$ & \multicolumn{2}{|r|}{$30 \%$} & \multicolumn{2}{|l|}{$8 \%$} & $0 \%$ \\
\hline Turkey & & $60 \%$ & \multicolumn{2}{|c|}{$56 \%$} & $41 \%$ & \multicolumn{2}{|r|}{$3 \%$} & $0 \%$ & & $0 \%$ \\
\hline \multicolumn{11}{|c|}{ b) Dislikes } \\
\hline & litter & $\begin{array}{c}\text { poor } \\
\text { focilities }\end{array}$ & $\begin{array}{l}\text { water } \\
\text { quality }\end{array}$ & Sewage & Smells & $\begin{array}{l}\text { Dog } \\
\text { mess }\end{array}$ & seaweed & $\begin{array}{l}\text { lock of } \\
\text { sond }\end{array}$ & noise & $\begin{array}{l}\text { poor } \\
\text { occess }\end{array}$ \\
\hline Malto & $50 \%$ & $8 \%$ & $15 \%$ & $20 \%$ & $10 \%$ & $15 \%$ & $28 \%$ & $60 \%$ & $43 \%$ & $15 \%$ \\
\hline Romania & $98 \%$ & 56 & $30 \%$ & $24 \%$ & $16 \%$ & $16 \%$ & $14 \%$ & $10 \%$ & $6 \%$ & $2 \%$ \\
\hline Turkey & $63 \%$ & $18 \%$ & $40 \%$ & $0 \%$ & $9 \%$ & $44 \%$ & $0 \%$ & $24 \%$ & $18 \%$ & $13 \%$ \\
\hline
\end{tabular}

c) Concern for beach management and specific suggestions for improvement:

\begin{tabular}{lccc}
\hline & Malto & Romanio & Turkey \\
\hline Coostol erosion & $60 \%$ & $46 \%$ & $63 \%$ \\
Speciol protection & $35 \%$ & $22 \%$ & $57 \%$ \\
Improvements & $70 \%$ & $72 \%$ & $36 \%$ \\
Suggestions & $53 \%$ & $60 \%$ & $34 \%$ \\
\hline
\end{tabular}

d) Improvements suggested

\begin{tabular}{lccc}
\hline & Malto & Romania & Turkey \\
\hline Better Sand \# & $42 \%$ & $42 \%$ & $16 \%$ \\
Better management & $3 \%$ & $12 \%$ & $3 \%$ \\
Protection from & $0 \%$ & $8 \%$ & $0 \%$ \\
erosion & & & \\
Leveller beach & $0 \%$ & $2 \%$ & $0 \%$ \\
Privatise beoch & $0 \%$ & $2 \%$ & $0 \%$ \\
More facilities & $19 \%$ & $0 \%$ & $12 \%$ \\
Less traffic & $2 \%$ & $0 \%$ & $0 \%$ \\
Better access & $3 \%$ & $0 \%$ & $3 \%$ \\
\hline
\end{tabular}

* Enjoyment of the beach is the stated proportion of the total holiday enjoyment.

\# better sand includes; cleaner, more of, texture, etc.

that domestic tounists do not perceive a different culture, food, history, language or climate when on holiday and thus assign a higher proportion af their enjoyment to beach activities. As expected, the value for St George's, Malta is even lower $(47 \%)$. This is likely to be due to the generally degraded nature af the existing sandy beach and the 'off-season' timing of the survey: In addition, the result may reflect the impact of the predominance of rocky shore within the bay and the general dissatisfaction of overseas beach users with this type of bathing platform (Micallef et al., 1998). The issue of beach nourishment at St
George's hos been well publicised in Malta and moy have roised domestic expectations, which moy also partially exploin the law enjoyment rotio faund on this beach.

Beoches were roted according to appearance (Table 3). The beach at Olu Deniz, Turkey, was perceived ta be much better than the beoch ot Mamaia, Romania with St George's, Malta having the lowest rating. The poar rating at $\mathrm{St}$ George's is partially due to its urban setting, predominance of rocky-shore, and depleted sand. This is demonstrated in Table 3, which shows the dislikes of beach users. The main dislike at St George's was the lack of sond, whereas for the ather two surveys it was litter, but litter and noise were also significant dislikes at St Gearge's. At Mamaia, litter, beach cleanliness and poor facilities were the most prevalent dislikes (Coman et al., 1999). The corresponding dislikes at Olu Deniz were dog mess and water quality. Some 54 $\%$ of Romanion respondents rated the beach as 'Good' but perceived a need for improvement. This need (Table 3) was lower for Olu Deniz, which was the mast highly rated beach and was similar for the other two beaches investigated. These findings are in keeping with similar work carried for beaches elsewhere (Morgan et al., 1995; Micallef et al. 1998).

No trend was found between the respondent's awareness of coastal erosion and or the need for special protection with their beach ratings. The number of respondents ot Mamaia \& St George's (the two lower rated beoches) suggesting o specific improvement was significantly lower than those wanting on unspecified im- 
provement. However, these levels of need for improvement (Table 3 ) are much higher than the figure for Olu Deniz. The main improvements suggested were better sand, more sand and cleaner sand which was the highest ranked response at oll three locations. More facilities was the second ranking suggestion for Malta and Turkey, whilst better monogement was ronked second in the Romanian survey. These findings should be of particulor interest to the praposed beach nourishment of St. George's Boy, Malto.

\section{c) Willingness To Pay}

The proportion of respondents willing to pay, wos similar for Mamaio, Romania and for Olu Deniz, Turkey, (Table 4). The amount respondents on St George's Beach, Malto, were willing to pay was significantly less. However, respondents on St George's Beach, who were willing to pay, were prepared to pay a larger amount (Table 4). The findings for Olu Deniz matched those from other Turkish beaches e.g. a WTP of $£ 0.89$ per day for beaches in the Cesme Peninsulo (Unal and Williams, 1999).

The majority of respondents in oll three surveys believed that children should not have to pay, but the figures supporting this view ore variable (Table 4). This does nat seem ta reflect the composition af the survey, as the Momoia, Romania sample hod the lowest support for this policy, despite hoving the highest percentage of family groups. It would appear that this is a cultural difference between a mainly local Romanian somple and mainly western European samples of the ather two lacations.

Were the amounts that respondents gave for WTP realistic? For Mamaia Romania, the average value corresponds to $11 \%$ of the respondent's average daily earning which is an order of magnitude greoter thon far the other two surveys. The Romanians also have a high cast of holidays to earnings rotio, ranging between I to 10 months of their average earnings with often the trade unian paying $40 \%$ of the cost of the holiday. Therefore, Romanian respondents may have a distorted picture of this market, or this moy be further evidence of cultural differences between Ramanians and the other nationolities surveyed.

To put the stated WTP into perspective, respondents were asked to nome activities that they found marginally more and marginally less
Table 4. Contingent valuation

\begin{tabular}{|c|c|c|c|}
\hline \multicolumn{4}{|c|}{$\begin{array}{l}\text { a) Respondents Willingness To Pay to maintain } \\
\text { or improve the beach: }\end{array}$} \\
\hline & Malta & Romania & Turkey \\
\hline $\begin{array}{l}\text { WTP } \\
\text { Av. value of } \\
\text { those WTP } \\
\text { Av. value of } \\
\text { whole sample } \\
\text { Av. WTP / } \\
\text { daily earnings } \\
\text { Children free }\end{array}$ & $\begin{array}{l}48 \% \\
£ 1.41 \\
£ 0.64 \\
0.013 \\
91 \%\end{array}$ & $\begin{array}{c}£ 0.37 \\
£ 0.32 \\
0.11 \\
40 \%\end{array}$ & $\begin{array}{c}£ 1.07 \\
£ 0.94 \\
0.024 \\
86 \%\end{array}$ \\
\hline \multicolumn{4}{|c|}{ b) Preferred method of payment: } \\
\hline & Malto & Romanio & Turkey \\
\hline Per visit & & $43 \%$ & $73 \%$ \\
\hline Tourist tox & $24 \%$ & $29 \%$ & $7 \%$ \\
\hline Voluntary box & $20 \%$ & $19 \%$ & $12 \%$ \\
\hline Car parking & $23 \%$ & $9 \%$ & $8 \%$ \\
\hline
\end{tabular}

enjoyable than visiting the beach and to soy how much they generally spent on them. These activities and their associated perceived expenditures are shown in Table 5. With the exception of one value (sightseeing at $£ 0.81$ ) oll expenditures given are greater than the users WTP for the beach. This is equally true for the marginally less enjoyable activities given by respondents in Malta and Romania, which is also shown in Table 5. Mead ond Sorensen (1970) faund that a visit to the beach is 1.74 times more enjoyoble than o visit to the cinema ond suggest thot the beach visit moy be volued at 1.74 times this cost. Such a valuation would produce figures greater than the WTP obtained in our surveys. Blokemore and Willioms (1998) found that $74 \%$ of British subjects surveyed in south-east Wales, were WTP and the mean value that respondents were WTP was $£ 1.25$ per visit. This moy be compared with British tourists WTP valuations of $£ 0.86$ for St George's Bay and $£ 0.95$ for Olu Deniz. In od. dition, Micollef (1996), identified that up to $57 \%$ of overseas beoch users interviewed in : survey on four prominent beaches in Molt: were willing to pay between 1 - 5 USS for wel manoged beaches. The author also noted the Moltese locols were frequently paying between $2: 25-4.50$ US $\$$ for the use of large outboor hatel swimming pools which possibly refiects 
Table 5. Enjoyment of other activities

a) Marginally more enjoyable activities than using the beach

\begin{tabular}{l|cc|cc|cc}
\hline & \multicolumn{2}{|c|}{ Romania } & \multicolumn{2}{c|}{ Molto } & \multicolumn{2}{c}{ Turkey } \\
& Frequency & $\begin{array}{c}\text { Perceived } \\
\text { Cast }\end{array}$ & Frequency & $\begin{array}{c}\text { Perceived } \\
\text { Cost }\end{array}$ & Frequency & $\begin{array}{c}\text { Perceived } \\
\text { cost }\end{array}$ \\
\hline Drinks in a bar & $14 \%$ & $£ 2.64$ & $2 \%$ & - & $0 \%$ & - \\
Water sports incl. boating & $14 \%$ & $£ 8.93$ & $5 \%$ & $£ 3$ & $16 \%$ & $£ 11$ \\
Sports & $8 \%$ & $£ 5.40$ & $0 \%$ & - & $7 \%$ & - \\
Shopping & $6 \%$ & $£ 6.50$ & $8 \%$ & - & $3 \%$ & - \\
Eating or picnic & $4 \%$ & $£ 6.50$ & $5 \%$ & $£ 14$ & $2 \%$ & $£ 10$ \\
Swimming Pool & $2 \%$ & $£ 2.03$ & $0 \%$ & - & $16 \%$ & - \\
Walking & $0 \%$ & - & $25 \%$ & - & $10 \%$ & - \\
Reoding & $0 \%$ & - & $3 \%$ & - & $3 \%$ & - \\
Sight seeing & $2 \%$ & $£ 0.81$ & $18 \%$ & $£ 7$ & $10 \%$ & $£ 10$ \\
Nothing better & $0 \%$ & - & $0 \%$ & - & $5 \%$ & - \\
\hline
\end{tabular}

b) Morginally less enjoyable activities:

\begin{tabular}{l|cc|cc}
\hline & \multicolumn{2}{|c|}{ Romania } & \multicolumn{2}{c}{ Malto } \\
& Frequency & Perceived Cost & Frequency & Perceived Cost \\
\hline Eating & $8 \%$ & $£ 6$ & $3 \%$ & $£ 5.50$ \\
Mini golf & - & - & $0 \%$ & - \\
Shopping & $18 \%$ & $£ i 2$ & $15 \%$ & - \\
Sight seeing & $4 \%$ & - & $2 \%$ & - \\
Swimming pool & - & - & $3 \%$ & - \\
Sport & $6 \%$ & - & $3 \%$ & - \\
Stay in & $22 \%$ & - & $3 \%$ & \\
Walking & - & & & \\
\hline
\end{tabular}

This question wos nat asked in the Turkish survey.

the viewpoint thot locals might also be willing ta pay for similarly well managed beaches. Dharmaratne and Brathwaite (1998) studied WTP far beach use in Borbados, their mean valuation wos equivalent to $£ 1.69$ per day. These comparisons further validate that the WTP values found in these surveys are affordable by the respondents and are realistic.
The relationship between the amount those who were willing to pay were prepared to pay per visit and their earnings is shown in Table 6. For those beaches where British tourists were the major users, four earning categories were used. The middle two categories represent bands based araund British average eornings and cover the ranges $67 \%$ to $100 \%$ and $101 \%$

Table 6 . Willingness to pay and earnings

\begin{tabular}{c|c|c|c|c|c}
\hline \multicolumn{2}{c|}{ St George's, Molto } & \multicolumn{2}{c|}{ Momaio, Romanio } & \multicolumn{2}{c}{ Olu Deniz, Turkey } \\
\hline Eornings £ pa & WTP £/visit & Earnings £ po & WTP £/visit & Eornings £ pa & WTP £/visit \\
\hline $27001-50000$ & 1.12 & $1440-4800$ & 0.43 & $27001-50000$ & 1.24 \\
$1800-27000$ & 1.02 & $871-1200$ & 0.36 & $1800-27000$ & 1.16 \\
$12001-18000$ & 0.93 & $600-870$ & 0.28 & $12000-18000$ & 1.10 \\
Below 12000 & 0.99 & 480 ond below & 0.21 & Below 12000 & 0.93 \\
\hline
\end{tabular}


Table 7. Willingness to pay for different social classes

\begin{tabular}{l|c|c|c|c|c|c}
\hline & \multicolumn{2}{|c|}{ St. George's, Malta } & \multicolumn{2}{c|}{ Mamaio, Romania } & \multicolumn{2}{c}{ Olu Deniz, Turkey } \\
\hline & \%WTP & WTP £/v & \%WTP & WTP E/v & \%WTP & WTP E/v \\
\hline Professianal & 29 & 2.02 & 84 & 0.38 & 91 & $0.93(1.01)$ \\
S, SS\& M & 44 & 1.09 & 81 & 0.32 & 97 & 0.96 \\
Retired, & 90 & 1.18 & 89 & 0.42 & 100 & 0.87 \\
Student, & & & & & & \\
Unemployed & & & & & & \\
\hline
\end{tabular}

Key: S - Skilled; SS Semi-skilled; M- Manual

to $150 \%$ of British overage earnings. The two remaining categaries represent earnings either side of these middle bands. The categories for Romonia (domestic use) are based around clusters found in the reported earnings of the respondents. All three samples show an increase in the average WTP as the earnings category increases.

Respondents were divided into three social classes based upon their accupations. The three groupings were: a) professionals, b) skilled, semi-skilled and manual workers and c) retired, student and unemployed respondents. Professionols were generally less likely to be willing to poy thon both other social groupings (Table 7). Those professionals who were willing, were prepared on overage to pay o higher amount per visit than the skilled, semi-skilled and manual workers group, however there was no clear trend for the retired, student and unemployed group in this respect.

If WTP is a true reflectian of a hypothetical market then users should display other market characteristics e.g. diminishing marginal utility. This is demanstrated in Table 8 for St George's Bay and for Mamaia in twa parameters: the amount respondents were WTP and the proportion of respondents WTP. A higher value of both parameters wos found for visits of shorter duration. The data for Olu Deniz is less cleor cut, due to the small number of respondents spending both short and long periods on the beach and the similarity of the results obtained for the two middle categories of beoch duration. Diminishing marginal utility was indicated by users of Olu Deniz Beach when beach use wos meosured using daily frequency (Table 9).

A weak inverse correlation between the beoch users roting af beach appearance and their WTP and the amount that those hoving a WTP were prepored to pay, is shown in Toble 10. Results from St George's and Olu Deniz showed a definite trend between the omounts those WTP would pay and their perception af need for improvement. The data for Mamaia was weaker showing that thase who rated the beach excellent were not prepared to poy as much as the other categories. Also, there is a weak trend for both, increased WTP and the amount respondents were willing to pay with lower beach rating. Over all three beaches a weak but cansistent trend was found. Eoch respondent stated how much they valued the porticular improvement(s) they would have liked. There is therefore, an inbuilt assumption that all the money raised would be spent on those improvements.

Table 8. Willingness to pay and beach use (duration)

\begin{tabular}{|c|c|c|c|c|c|c|}
\hline \multirow[b]{2}{*}{$\begin{array}{l}\text { Duration an } \\
\text { beach } \\
\text { (hours/day) }\end{array}$} & \multicolumn{2}{|c|}{ St George's, Malta } & \multicolumn{2}{|c|}{ Mamaia, Ramania } & \multicolumn{2}{|c|}{ Olu Deniz, Turkey } \\
\hline & $\underset{\%}{W T P}$ & $\begin{array}{c}\text { amount WTP } \\
£ \text { per visit }\end{array}$ & $\begin{array}{c}\text { W T P } \\
\%\end{array}$ & $\begin{array}{c}\text { amount WTP } \\
£ \text { per visit }\end{array}$ & $\begin{array}{c}\text { W T P } \\
\%\end{array}$ & $\begin{array}{c}\text { amount WTP } \\
£ \text { per visit }\end{array}$ \\
\hline $\begin{array}{l}\text { less than I } \\
1-4 \\
4-8 \\
\text { mare than } 8\end{array}$ & $\begin{array}{c}75 \\
67 \\
50 \\
0\end{array}$ & $\begin{array}{c}1.67 \\
1.01 \\
\text { VSR } \\
0\end{array}$ & $\begin{array}{l}- \\
93 \\
72 \\
75\end{array}$ & $\begin{array}{l}0.38 \\
0.34 \\
0.20\end{array}$ & $\begin{array}{c}100 \\
97 \\
98 \\
57\end{array}$ & $\begin{array}{l}\text { VSR } \\
0.97 \\
0.99 \\
\text { VSR }\end{array}$ \\
\hline
\end{tabular}

Note: the Very Small Respanse (VSR) obtained in some categories. 
Beach users may be misinterpreting the beach rating, in the sense that an excellent beach rating may additionolly imply 'good value for money' and vice versa for a poor rating. This would of course influence (reduce) their willingness to pay since their excellent rating is partially dependent on the free access status of the beach. However, the strongest correlation occurs for beaches used mainly by foreign tourists. The amount fareign tourists ore willing to pay is almost insignificant compored with their total holiday cost. Thus, it is unlikely that this interoction is significant.

The preferred mode of payment in all three surveys was to pay per visit (Table 4 ) and this was a clear majority response in Olu Deniz. A tourist tax goined some support in both St Georges and Mamaia but had a low response rate in Olu Deniz. The relative popularity of a tax payment system in Romania might be postulated to derive from a greater acceptance of central control i.e. perhaps ex-communist countries have more faith in government or less experience of free markets. However, this is not so os there is on existing "resort tox" at Mamaia, a $2 \%$ surcharge on hotel chorges is in operation. The revenue is explicitly for maintaining o clean resort but litter is still evidenced on the beaches. Also franchises for private beaches have been granted with opportunities for commercial activities in return for cleaner beoches. Therefore, there is a newly develaped beach market in operation in Romania.

\section{d) Travel Cost and Cansumer Surplus}

Tourists travelling to the beach from their accommodation took only a short duration, typically 5-20 minutes and in the main found the experience enjoyable, therefore, na significant opportunity cost was incurred. Therefore, this
Table 9. Willingness to pay and beach use (frequency) for Olu Deniz

\begin{tabular}{l|c|c|c|c|c}
\hline & $\begin{array}{c}\text { Every } \\
\text { day }\end{array}$ & $\begin{array}{c}\text { Most } \\
\text { days }\end{array}$ & $2-3$ days & 1 day & rare \\
\hline WTP & $40 \%$ & $67 \%$ & $50 \%$ & - & - \\
\hline $\begin{array}{l}\text { Ave. } \\
\text { value } \\
\text { per visit }\end{array}$ & $£ 0.93$ & 1.15 & 1.34 & - & - \\
\hline
\end{tabular}

element was excluded in the calculation of their travel costs below. Opportunity cost is the cost of time spent travelling to and from the site and is calculated based on a fraction of the respondent's hourly wage. The exact fraction to use has been the subject of debate, o review is given by Bateman (1993). If the respondent enjoyed the trip it can be argued that there is no opportunity cost.

\section{Mamaia Beach, Romonia}

Time spent travelling to the resort and returning to the respondents home averaged 5.3 hours for domestic tourists, but the opportunity cost of this time was small compared to their actual holiday expenditure (comprising $0.25 \%$ to $3.5 \%$ of total expenditure) and so this debatable cost has been excluded. The remaining cost of the holiday for domestic tourists ranged between $£ 81.16$ ta $£ 811.60$. The demand curve generated by dividing the tourists into short stay (3-5doys) and long stay (6-12 days) gave Consumer Surpluses of $£ 0.71$ and $£ 0.68$ per odult per beach visit respectively. The average value for damestic tourists was higher than that found for local beach users (Table 11). Consumer surplus is the difference between the consumer's valuation of a good or service, i.e. whot they are winning to pay for the good or service, and the market price they actually pay. If the seller could segment the mar-

Table 10. Willingness to poy and beoch oppearance rating

\begin{tabular}{l|c|c|c|c|c|c}
\hline & \multicolumn{2}{|c|}{ St. George's, Malta } & \multicolumn{2}{c|}{ Mamaia, Romania } & \multicolumn{2}{c}{ Olu Deniz, Turkey } \\
\hline & WTP \% & WTP £N & WTP \% & WTP £N & WTP \% & WTP £N \\
\hline Excellent & 40 & VSR & 75 & 0.23 & 79 & 1.01 \\
Good & 44 & 1.03 & 81 & 0.39 & 97 & 1.29 \\
Fair & 40 & 1.04 & 87 & 0.36 & VSR & VSR \\
Poor & 75 & 1.22 & 75 & 0.38 & - & - \\
Very Bad & $50 *$ & VSR & - & - & - & - \\
\hline
\end{tabular}

* denotes resuit heavily influenced by local residents 
F Brian Blakemore, Allan T. Williams, Claudia Coman, Anton Micallef, Ozlem Unal

Table 11. A comparison of WTP and CS for local, domestic and foreign beoch users

\begin{tabular}{|c|c|c|c|c|c|c|}
\hline & St George's & Malta & Mamaia & Romanio & Olu Deniz & Turkey \\
\hline & WTP $£ / v$ & $C S £ / v$ & WTP $£ / v$ & $C S E / v$ & WTP $£ / v$ & $C S E / v$ \\
\hline $\begin{array}{l}\text { Locals } \\
\text { domestic } \\
8 \text { ritish } \\
\text { Dutch }\end{array}$ & $\begin{array}{l}0.39 \\
\text { VSR } \\
0.86 \\
0.55\end{array}$ & $\begin{array}{l}1.08 \\
\text { VSR } \\
0.62 \\
0.30\end{array}$ & $\begin{array}{c}0.28 \\
0.37 \\
- \\
-\end{array}$ & $\begin{array}{c}0.39 \\
0.69 \\
- \\
-\end{array}$ & $\begin{array}{l}0.55 \\
0.74 \\
0.95\end{array}$ & $\begin{array}{l}\text { VSR } \\
0.46 \\
0.63\end{array}$ \\
\hline
\end{tabular}

VSR denotes very small response

ket, so thot, each consumer purchased the good or service at their own WTP, then the consumer surplus would be extra soles revenue. For a straight line, downward sloping demand curve, the consumer surplus is the triongular orea under the curve between zero demand at the maximum WTP and the actual demand at the morket price.

\section{St George's Bay, Malta}

Travel time between accommodotion and the beach wos essentially the same for all fareign tourists, therefore, excluding this opportunity cost ollows consistency with the other beaches and does nat affect the value of the consumer surplus calculated from the travel costs. The remaining cost of the holiday was on overage; $£ 381$ far British visitors and $£ 387$ for Dutch visitors. The cansumer surplus wos found to be highest for locals, followed by British tourists and then Dutch taurists (Table 11).

\section{Olu Deniz, Turkey}

Average expenditure on the holiday pockage was $£ 230$ for British tourists (the main tourists at this beach) and their consumer surplus was found to be higher thon that af domestic tourists (Toble 11).

In each case, it wos found that there were two dominant positions on the travel cost demond schedule, i.e., two data points. Thus, a linear relationship is ossumed in each case. Spearman's carrelation coefficient for a straight line formed from two data points must be 1.0 . However, this does not prove thot there is in foct a linear relotionship. Many studies have used a linear relationship between travel cost and demond for example, Bell and Leeworthy (1986) and Brown (1993).

\section{Comparison and Policy Implications}

The consumer surplus (CS) of locals is less than that of domestic tourists for Mamaia; this is also true for the WTP per visit. These trends are echoed ot Olu Deniz, but the very small sample of locals at Olu Deniz prevented the colculation of a meaningful CS for them (see Table 11). Similarly the smoll sample size af domestic tourists at St George's Boy precluded comparison with this group. The CS for locols at St George's is considerably higher than for any other group. In general it could be postulated that the dato shows that foreign tourists have higher valuatians (WTP and CS) than domestic tourists, who in turn hove a higher valuation than lacal beoch users. However, it must be remembered that foreign tourists also had higher incomes than the domestic populations in our study. Therefore, it would oppeor that the high value found for the locol beoch users on St George's Bay $(n=10)$, is atypical. The CS af British tourists on St George's bay was found to be within one pence of that of British tourists on Olu Deniz Beach (£0.62 and $£ 0.63$ respectively, Table 11).

Economic theory requires CS to be less than WTP for a propased gain or loss of welfare (Bateman and Turner, 1993). In our survey the respondent was asked how much they were prepared to pay to maintain and/or improve the beach. Thus, a weak farm of welfare goin is investigated. In this situation, WTP is o measure of compensating surplus. The Consumer Surplus calculated from the travel cost dota is based upan a use valuation only, whereas WTP may olso include non-use values and this wider valuation may allow the WTP ta exceed the CS. A relatively higher figure for WTP implies that respondents are not only giving o market (use) value but olso an existence and/or an option value for the beach. In the Romanion survey, CS was greoter thon WTP, but this was not the cose for Malta and Turkey. The close proximity of WTP and CS values faund far each category of beach user (again excluding the local beach users in Molto) despite the small sample sizes 
used, validates the robustness of the samples taken ond the methods used.

It has been suggested that the WTP found from the Contingent Valuation Method is downward biased. Bishop and Heberlein (1979), compared a hypothetical WTP with an actual market price and found that WTP was considerably lower. This does not oppear to have occurred in this study os the WTP was found to be similar to and/or greater than the CS.

The type of dato presented provides for sound rotional decision making regarding beoch manogement guidelines accarding to Williams and Dovies (1998). The demographic surveys give an indicotion of the oge structure, social class of the beach user and amenities con be tajlared to suit this category of taurist. The WTP of different user groups indicotes how people are prepared to sacrifice spending money for the soke of beoch improvements. It is important to stress that people are only prepared to pay if the money is collected locolly and spent purely on beach facilities. In the cose of Turkey, it provides o strong argument for a chonge to existing law. It may imply that independent trusts or chonities shauld be used to collect and spend such revenues. It certainly argues for good cammunication between beoch managers and beoch users. Beach managers need to communicate how the quality of the experience has and is being improved, the costs involved and the revenue raised from beoch use.

In Romania recent changes in the law have enabled both commercial develapment and better management of the beaches: In 1998, the "National Company Romanian Water" (NCRW) was made the manager of the Ramanian beaches (HG981, 1998). Exclusions from this control are beoches and cliffs monaged by the Notional Company of Maritime Constanta Harbour and the "Donube Delta" reservation. The best results from this tronsition can be seen on Momoia Beach. Beach facilities developed on private beoches in the last year (2000), included; provision of litter bins, showers, beds and sunshades. Unfortunately, some beach commercial agents are not fulfilling their contractual obligotions (e.g. litter is not collected).

One of the clauses, in the Romonian government legislation, HGIOT (1996), stipuloted that during 2000 the commerciol ogents should present projects to obtain o beach classification in the cotegory one dolphin e.g., providing and upgrading toilets and showers. HG 107 allows the beach commercial agents to sell soft drinks and packaged foods. Without this development itinerant commercial trade is encouraged on the beach, offering products thot may be unhygienic. This itinerant trade continues to exist on beaches with no action being taken by local authorities. None of the respandents on Mamaia Beach cited itinerant trade os a dislike. However, this unofficial trade may damage the official agent's profitobility and so threaten the success af this appraoch.

At present in Romanio there are no charges for tourists to enter privatised beoches. Only Constanto Beoch, which is a public beach, has implemented charges for tourists. A commercial agent manages the beach and is required to develop the tourist potential of the beach (HG514, 1998). The charge (tox) for one person is $£ 0.12$ /person (3000 lei/person).Our study suggests that this charge could be increased further. The way to further utilise the beach from a commercial point of view is being studied through tourism experts provided by the German government at the request of NCRW. The final report will show if the strotegy adopted is appropriote for Romania.

\section{Conclusions}

Beoch users had many common factors such as: age, group size, classification by employment, duration of vocation, frequency of use, time spent on activities pursued on the beach. The main differences were: the high proportion of notionals on the beach at Mamaia, their considerably higher evaluation of beach enjoyment compared to total enjoyment of their vacation and the off peak season sample periad ot St George's Bay.

The three beoches studied represented the range: fair, good or excellent appeorance ratings, as judged by their surveyed users (Toble 3). The most importont priority for improving all three beoches was to have more sand, better sond and cleaner sand. A weak correlation between increased WTP with a lower beach rating wos found which suggests thot respondents are prepared to pay mare when the perceived need for improvement is higher. 
The proportion of respondents who expressed a WTP was similar on all three beaches. Although the average amount that the beach users were WTP an Mamaia was half that found on the other two beaches, it represents a very high ratio of WTP to average daily earnings. This suggests a different socio-economic attitude for Romanians compared to the other nationalities surveyed

On oll three beoches, trends were faund that suggest that respondents WTP increoses with earnings. The variotion af WTP with accupatianal groupings suggests thot prafessionol people are less likely to hove o WTP but those thot are willing ore prepared to pay mare. A thorough understanding of these trends is essentiol to both tourism and coastal managers when a shift in beach user demographics is planned (Turkey) or expected, as may be the case on Constonta Beach, Romania, fallowing the introduction af chorging for beach use.

Diminishing Marginal Utility (DMU), as measured by WTP, with beach use was found in all three surveys. Foreign tourists from wealthy countries were prepared to pay more than domestic tourists were, who in turn, were prepared to pay more than local beach users.

Coastal Zone Managers need to take account of DMU when setting prices for beach use. Beaches with higher use by locols or tourists that spend longer an the beach will not tolerate the higher price that infrequent or shorter stay users will occept. This could result in a seasonal pricing structure with higher charges in the off season when users spend less time on the beach! In practice it is unlikely that different prices can be set for different market segments, so the price will be constrained by the most price sensitive segment, unless the oim is to reduce beach use in order to moximise revenue.

The preferred mode of payment was via a payment per visit ta the beach for adults only. This maybe due to respondents familiarity with this type of payment in everyday transactions, or it maybe a manifestation of their desire ta see the revenue directly linked to expenditure on the improvements. This form of charging is likely to be difficult to implement on most beoches, except where a convenient access point occurs as at Olu Deniz and potentially at St George's. This would require a change in the coastal law in Turkey, but results given in this paper indicate that this is what peaple seem to desire.

Good agreement was found on the respondent's valuation of a beach visit using contingent valuation (WTP) and travel cost (CS) methads. The validity of these valuatians wos further justified by comparing respandent's expenditure on other leisure activities.

The similarity af the results found across the three surveys and between this work and that of others (Morgan and Williams, 1998; Blakemore and Willioms, 1998; Anon. 1988; Coman ef al., 1999; Morgon et al., 1995, Dharmaratne and Brathwaite, 1998; and Micallef et al., 1999) suggests that reseorchers can use small samples to good effect in aiding caastal zone management.

Contingent valuation and travel cost techniques con aid palicy formotion and manogement decision making for the provision of free recreational facilities. However, the values found from such techniques are only opproximate at best ond require; o realistic and unambiguaus scenario for the respondent to volue in the case of the CVM, and careful explorotion of the true costs ond benefits associated with the visit in the case of the TCM.

Further work is required to develop a fuller understanding of the beach evaluation process and to compare tourist evaluations of a wider range of beaches, beoch use and for a wider range of cultures.

\section{Acknowledgements}

We would like to thonk the participants of MEDCOAST, 1999 who undertook the fieldwork at Olu Deniz Beoch. Feyzo Surucu (Ministry of Tourism, Ankara, Turkey) ond Prof Erdol Ozhon, (METU, Ankoro, Turkey), provided excellent help in the mony discussions that took place during this project. In oddition, we would like to thank The British Council, Ankoro, Turkey ond the British Council, Valetta, Molta, for the finonciol assistance thot mode this project possible.

\section{REFERENCES}

Anon. 1988. Beach usoge and beach user characteristics. Australion Bureou of Stotistics, Adelaide, 5000 , Austrolia.

Anon. 2001. Turkish News, Ankora, April 2, p5. 
Boteman, IJ. and Turner, R.K.( Ed) 1993. Sustainable environmental economics and management principles and practice. London, Bellhaven: 136-146

Bell, F.W and Leeworthy, V.R 1986. An economic analysis of the importance of saltwater beaches in Florida. Dept. of Economics, Report 82. Florida State University, Tollohosse.

Bishop, RC. and Heberlein, T. A. 1979. Measuring volues of extramarket goods: Are indirect measures biosed? American Journal of Agricultural Economics December, 926-930.

Blakemore, F.B, and Williams, A.T. 1998. Public evaluation of beaches in south east Wales, UK. Shore and Beach.66 (4), 18-23.

Blakemore, F.B, Williams, A.T. and Ozhan, E. 2000. Tourist evaluation of Olu Deniz beach (Turkey) using contingent valuation and travel cost approaches. World Leisure, No 4, 48-55.

Brown Jr., G. 1993. The viewing value of elephants. Economics and ecology, (ed.) Barbier, E.B. pp 146-55. London. Chapman \& Hall.

BTS, 1999. Bulletin of Tourism Statistics, Ankara Ministry of Tourism. Pp 84

Coman, C., Morgan, R. and Williams, A.T. 1999. The need for beach management. A case study of Mamaia beach, Romania. (In). Proceedings of the MEDCOAST EMECS 99 Joint Conference, Land-Ocean Interactions: Managing Coastal Ecosystems, (ed.) E. Ozhan, 935-960, MEDCOAST, METU, Ankara, Turkey.

Dharmaratne, G.S. and Brathwaite, A.E. 1998. Economic valuation of the coastline in Bardados, Journal of Travel Research, 37 (2), 138-144.

HG107, 1996. Official Monitor, Bucharest, Romanian government, Number 48 .

HG514, 1998. Official Monitor, Bucharest, Romanian government, Number 312.

HG981, 1998. Official Monitor, Bucharest, Romanian government, Number 530 .

Hinde, S. 1998. Who earns what in nineties Britain. The Express. October 7th. London.

Houston, J.R 1996. International Tourism and US beaches. Coastal Engineering Research Centre (CERC), 96-2, 1-3.

MMT 1999. Tourism Carrying Capacity Assessment of the Maltese Islands - an Executive Brief, Ministry for Tourism, Valletta, Malta. pp34

Mead, W. and Sorensen, P. 1970. The economic cost of the Santa Barbara oil spill. Santa Barbara oil symposium, University of California, 183-226.

Med. Economique. 1997. Mediterrannee Economique: Premier report sur la situation des Pays Riverans au debut des annees, CEFI-Economica.

Micallef, A., Morgan, R., and Williams, A. T. 1998. User Preferences and Priorities on Maltese Beaches: Findings and Potential Importance for Tourism. (In), Coastal Environmental Management, (ed.), G. Randazzo, EUCCItaly/EUCC 1999. (Electronic publishing, $11 \mathrm{pp}$ ).

NTOM 1997. National Tourism Organisation of Malta, 1997. 1996 Tourism Statistics, NTOM, Valletta, Malta. pp. 16

Morgan, R., Bursalioglu, B., Hapoglu-Balas, L., Jones, T.C., Ozhan, E. \& Williams,A.T. 1995. Beach user opinions and beach ratings: A pilot study on the Turkish
Aegean Coost. Proceedings of the second internationa conference on the Mediterranean coastal environment. (ed.). E. Ozhan, 273-83, MEDCOAST, METU, Ankara, Turkey.

Morgan., R and Williams, A.T., 1998. Beach Ratings - what are they worth? Current Quality. edition 2. Jan., 2 . Copenhagen WHO Regional Office Europe.

Raybould, M and Mules, T. 1996. A cost-benefit study of protection of the northern beaches of Australia's Gold Coast. Tourism Economics, 5 (2). 121-139.

Unal, O and Williams, A.T. 1999. Beach visits and Willingness to Pay: Cesme Peninsula, Turkey. Proceedings of the MEDCOAST-EMECS 99 Joint Conference, Land-Ocean Interactions: Managing Coastal Ecosystems, (ed.) E Ozhan, 1149-1162, MEDCOAST, METU, Ankara, Turkey

Williams, A.T, and Davies, P. 1998. Beach Management Guidelines: Dimensional Analysis. (In), Coastal Environmental Management, (ed.), G Randazzo, EUCC Italy/EUCC, 1999. (Electronic publishing, 10pp)

Williams, A.T., Morgan, R., Ozhan, E. and Ergin,A. 2000. An investigation of beach aesthetics for the Antalyo to Izmir coastline of Turkey: a critique of current beach aesthetic analyses. Period. Biol. Vol. 102(1). 571-578.

\section{F. BRIAN BLAKEMORE} Senior lecturer

Centre for Environmental Science and Technology

School of Applied Sciences

University of Glamorgan, Pontypridd, Wales, UK.

ALLAN T. WILLIAMS

Managing Director Air Terra Water Ltd. Environmental Consultants

21 Beach Rd, Newton, Porthcawl, UK.

Professor

International Hurricane Centre

Florida International University Miami, USA.

CLAUDIA COMAN

Focal point CZM, Romanio

National Institute for Marine Research and Development

Blvd. Mamaia, no. 300, Constanta 8700 , Romania

ANTON MICALLEF, Director, ICoD, Foundation for International Studies, University of Malta

St Paul St. Valetta, Malta

OZLEM UNAL

Senior lecturer

Department of Urban \& Regional Planning

Faculty of Architecture Dokuz Eylul University Alsancak, Izmir, Turkey 